NOTICE: this is the author's version of a work that was accepted for publication in Groundwater (ISSN: 0017-467X, ESSN: 17456584). Changes resulting from the publishing process, such as peer review, editing, corrections, structural formatting, and other quality control mechanisms may not be reflected in this document. Changes may have been made to this work since it was submitted for publication. Early online view 4 April 2013. A definitive version was subsequently published in GROUNDWATER, VOL 52, ISSUE 22, (2014), pp.251-263, DOI: 10.1111/gwat.12057.

\title{
Detection of mixing dynamics during pumping of a flooded coal mine
}

Trevor Elliot ${ }^{\mathrm{a},},{ }^{*}$, Paul L. Younger ${ }^{\mathrm{b}}$

${ }^{a}$ EERC Environmental Tracers Laboratory, Environmental Engineering Research Centre, School of Planning, Architecture and Civil Engineering, Queen's University Belfast, BT9 5AG. Northern Ireland/UK

${ }^{\mathrm{b}}$ School of Engineering, University of Glasgow, James Watt Building (South), Glasgow G12 8QQ, Scotland. (paul.younger@glasgow.ac.uk)

* Corresponding Author. Tel.: +44 28-90974736; fax: +44 28-90663754)

E-mail address: t.elliot@qub.ac.uk (T. Elliot)

\begin{abstract}
In complex hydrogeological environments the effective management of groundwater quality problems by pump-and-treat operations can be most confidently achieved if the mixing dynamics induced within the aquifer by pumping are well understood. The utility of isotopic environmental tracers (C-, H-, $\mathrm{O}-$, S- stable isotopic analyses and age indicators $-{ }^{14} \mathrm{C},{ }^{3} \mathrm{H}$ ) for this purpose is illustrated by the analysis of a pumping test in an abstraction borehole drilled into flooded, abandoned coal mineworkings at Deerplay (Lancashire, UK). Interpretation of the isotope data was undertaken conjunctively with that of major ion hydrochemistry, and interpreted in the context of the particular hydraulic setting of flooded mineworkings to identify the sources and mixing of water qualities in the groundwater system. Initial pumping showed breakdown of initial water quality stratification in the borehole, and gave evidence for distinctive isotopic signatures $\left(\delta^{34} \mathrm{~S}(\mathrm{SO} 4) \cong-1.6 \%\right.$, $\delta^{18} \mathrm{O}\left(\mathrm{SO}_{4}\right) \cong+15 \%$ ) associated with primary oxidation of pyrite in the zone of water table fluctuation - the first time this phenomenon has been successfully characterised by these isotopes in a flooded mine system. The overall aim of the test pumping- to replace an uncontrolled outflow from a mine entrance in an inconvenient location with a pumped discharge on a site where treatment could be provided - was swiftly achieved. Environmental tracing data illustrated the benefits of pumping as little as possible to attain this aim, as higher rates of pumping induced in-mixing of poorer quality waters from more distant old workings, and / or renewed pyrite oxidation in the shallow subsurface.
\end{abstract}

Keywords Flooded mine discharge control $\cdot$ acid mine drainage $\cdot$ Deerplay (Lancashire, UK) · environmental tracers $\cdot$ stepped pump test

\section{Introduction}

In traditional water well investigations to obtain drinking water supplies, there is seldom much need to analyse the provenance and mixing of distinct bodies of groundwater (e.g. Todd 1980). Whilst it is common to monitor water quality during pumping tests, this is often restricted to collecting water samples for chemical analyses at the beginning and end of the test, with continuous monitoring of electrical conductivity and temperature during the test, with further samples only being collected if there is a marked change in conductivity. For sensitive uses, more intense monitoring will sometimes be undertaken. For instance Elschami (1991) monitored dissolved major ions at several irrigation wells pumped over a 24hours period to identify whether there were any significant changes in hydrochemical facies which can affect irrigation use of water. However, in coastal aquifers under threat of saline intrusion, or in 
contaminated aquifers, it is often desirable to be able to distinguish between groundwaters with different qualities (e.g. Domenico and Schwartz 1997). Under ambient flow conditions, such as in transport of a plume of leachate through an otherwise undisturbed aquifer, such issues are often addressed by multi-level sampling using temporary and permanent packers (e.g. Einarson and Cherry 2002). Such investigations often reveal that relatively little mixing of discrete pockets of water occurs within the aquifer itself (e.g. Wilson et al. 2004), which is indeed what one would expect under predominantly laminar flow conditions. Under such conditions, mixing is largely restricted to some combination of molecular diffusion and porescale blending at plume margins due to microscopic flowpath tortuosity (Domenico and Schwartz 1997). When such aquifers are pumped however, mixing might well be induced, both within parts of the aquifer subjected to higher groundwater flow velocities, and indubitably within any pumping well that penetrates more than one zone of stratified water quality within the aquifer. Such is the case, for instance, in pumpand-treat remediation schemes, where abstraction wells are used to remove polluted water from an aquifer for treatment and subsequent surface discharge or reinjection (e.g. US EPA 1996).

For all that within-aquifer mixing is often assumed to be induced by pumping, the phenomenon rarely has been documented in detail - at least outside of areas of saline intrusion. Mixing can be expected to be particularly acute in groundwater systems characterised by potential turbulent flow in large open voids, such as in natural karst systems or flooded underground mine workings. However, conventional aquifer monitoring approaches using observation wells are particularly challenging in such environments (Younger et al. 2002) and there is considerable value in assessing the scope for detecting within-aquifer mixing dynamics by studying variations in water quality experiences in the pumped abstraction wells. One of the most promising ways to do this is to study the so-called "environmental tracers" which comprise either natural (ambient) or anthropogenic (man-made) compounds that are widely distributed in the nearsurface environment of the Earth. Such compounds may be introduced into the hydrological system from the Earth's atmosphere during recharge, and/or are added/lost/exchanged inherently as waters flow over and through materials. Variations in their chemical abundances and isotopic compositions can be used as tracers to determine sources (provenance), pathways (of reaction/interaction) and also timescales (dating) of environmental processes (cf. Mink et al. 1972; Mayo et al. 1992; Zhou et al. 1993; Ahmad et al., 2003; Parry et al. 2000; Ziegler \& Middleton 2011; Sanford et al. 2011) which allow characterisation of both water sources and mixing effects (eg Faure and Mensing 2005).

This paper provides a rare worked example of the application of environmental tracers to detect groundwater sources and mixing dynamics in a system of large inter-connected underground voids, which could be regarded as a pseudo-karstic system, comprising the abandoned, flooded underground workings of a coal mine. Large systems of interconnected mine voids are often pervasively contaminated, and represent major instances of anthropogenic aquifers which release acidic and / or metalliferous groundwaters to surface catchments, causing major degradation of water quality (Younger et al. 2002). Previous investigations of such systems (e.g. Elliot and Younger 2007; Bailey et al. 2011) have successfully identified waters of different origins flowing through complex, multi-layer workings. In the case presented here, a newly-drilled abstraction borehole (hereafter referred to as " $A b s$ ") had been installed during development of a major, permanent pump-and-treat system to alleviate acidic mine pollution of a nearby river that had already persisted for more than 30 years. The borehole was subjected to a ten-week stepped-rate pumping test, during which sampling and analysis was undertaken for a complementary suite of $(\mathrm{C}, \mathrm{H}, \mathrm{O}, \mathrm{S})$ isotopic analyses and age indicators $\left({ }^{3} \mathrm{H},{ }^{14} \mathrm{C}\right)$, to help elucidate variations in groundwater quality and mixing dynamics within the flooded workings. Similar approaches are beginning to be taken in more typical public supply aquifers. For instance, Brown et al. (2002) monitored water-quality and select stable isotopes $\left(\delta^{13} \mathrm{C}\right.$ and $\left.\delta^{34} \mathrm{~S}\right)$ as environmental tracers in a public-supply well over a 2-day pumping test, with the hope of identifying contributory factors to bio-fouling. In that case, the environmental isotope data revealed that continuous pumping of the aquifer was inducing downward flow of shallow, oxygenated water, despite locally confined conditions. We report similarly revealing results for a mine system here, including demonstrating for the first time the ability of these environmental tracers to detect unsuspected 
deep stores of key pollutants - which is of prime importance in assessing the longevity of pollutant generation requiring pump-and-treat interventions (e.g. Younger 1997, 2000; Younger et al. 2002). We believe our results underline the added value which environmental isotope analyses can bring to conventional aquifer evaluation procedures.

\section{Study system}

The study system is in the abandoned (flooded) Deerplay Colliery [National Grid Reference, NGR 38705 42665] in Lancashire (north-west England, UK). This mine was interconnected underground to at least two others (Black Clough, Hill Top: see Supporting Information (SI) - History of the Deerplay workings). Deerplay Mine closed in 1968 and operational pumping to dewater the three connected collieries ceased about the same time, allowing natural water table rebound in the system. Just six months later, a highly ferruginous, uncontrolled discharge of groundwater commenced from an adit (i.e. a nearhorizontal drainage tunnel excavated in from a hillside location) known as the Black Clough Waterloose. The outflow from this adit polluted up to $7 \mathrm{~km}$ of local watercourses, including $1.5 \mathrm{~km}$ of the Black Clough stream before its confluence with the River Calder (Barnes 2000; Banwart \& Malmström 2001). Because of the steep nature of the ground in the immediate vicinity of the portal of the Black Clough Waterloose, it proved unfeasible to collect the drainage from the adit and divert it to a treatment works. Therefore, in 1999 IMC Consulting Engineers were commissioned by the UK Coal Authority to drill an Abstraction Borehole $(A b s)$ on Deerplay Moor. The purpose of subsequent test pumping of the $A b s$ borehole in 2000 then was both to test hydraulic interconnectivities of the workings and to pump the minewater at a sufficient rate to draw down, and hence prevent, the uncontrolled discharges occurring at Black Clough adit, as the prelude to the subsequent installation of a pump-and-treat plant to eliminate the water pollution problem in perpetuity (cf. Bailey et al. 2011; Wireman \& Stover 2011).

The logged borehole section for the drilled $A b s$ borehole shows an alternating rhythmic sequence (cyclothem) of predominantly mudstone and sandstone, with interbedded coal seams (Fig.1). The old workings at Deerplay Mine reflect a relatively simple system of bord-and-pillar workings within a single coal seam - the so-called "Lower Mountain Mine" (LM) seam, which was found to lie at $144.5 \mathrm{~m}$ below surface (= $409 \mathrm{~m}$ above sea level, i.e. 409mAOD, signifying 'metres Above Ordnance Datum', which is the UK national sea level datum; Fig.1a). The apparent simplicity of having a single worked seam is complicated in practice by the presence of folding, which leads to considerable variation in the position of workings in Deerplay and adjoining collieries, with barriers of unworked strata in some places being traversed only by single mine roadways (i.e. tunnels through which miners travelled and materials were transported). The lowest of these roadway connections lies at $327.8 \mathrm{mAOD}$ ); Fig.1c). Deerplay Colliery historically was linked intimately with the Black Clough Colliery just to the north through pillar-and-stall connections, forming then a single set of mine workings. The Black Clough adit portal (332.5m AOD) is at the northern end of these workings (Figs.1a,c). To the NW, there was originally a small roadway connection (323 mAOD) also to Easden Wood Colliery, which however has collapsed. The Deerplay workings are bounded to the south and east by Hill Top Colliery, with which a direct connection is recorded via an in-seam drainage borehole (at $275.4 \mathrm{mAOD}$ ) and via a roadway (at $256.0 \mathrm{mAOD}$ ). The Deerplay Fault then forms the SW boundary to these workings (Fig.1c).

The Abstraction (Abs) Borehole on Deerplay Moor [NGR 387028, 426710] was drilled to intersect a crossroads in a roadway in the LM seam within the old Deerplay (western) workings. Old workings were encountered at $266.0-264.5 \mathrm{mAOD}(143-144.5 \mathrm{~m}$ below ground level (mbgl)) with an estimated void height of $1.5 \mathrm{~m}$ (IMC Consulting Engineers, 2000). These then supply the main water intake (in the LM seam) to the $A b s$ Borehole during pumping.

An electric submersible pump capable of pumping $>30 \mathrm{~L} / \mathrm{s}$ at the anticipated drawdowns of several tens of metres was suspended in the uncased borehole at a depth of around 118.5-120 mbgl (289-290.5 mAOD). The initial water level was $333.29 \mathrm{mAOD}$ at start of test. During the test pumping of the $A b s$ borehole (see SI - Test pumping of the Abstraction Borehole on Deerplay Moor) the discharge was 
pumped from the borehole to an aeration tower in the corner of one of two settling lagoons on site. After settlement in the lagoons to remove iron, the treated minewater then was released to the River Irwell (cf. Barnes, 2000, their Fig.1) which flows SW into the Manchester Ship Canal, thereby diverting this water discharge away from the River Calder.

Flooded (abandoned) underground mines are typically hydrochemically stratified with fresher waters overlying more brackish waters (Nuttall \& Younger 2004). Once flooded, less-mineralised, shallowsourced waters enter at the top of the water table and more heavily-mineralised (denser) water tends to remain at the base in the system until hydraulically disturbed. For the given dimensions (SI - Table S2) the turnover time for storage in the $A b s$ borehole at even the lowest pumping speed of $7.5 \mathrm{l} / \mathrm{s}$ would be a matter of only tens of minutes. To monitor and assess mixing dynamics at the $A b s$ Borehole, several pumped water samples were collected for environmental isotopes specifically at certain stages during the test schedule. Throughout the test pumping water samples for major and minor element hydrochemistry also were collected directly from the $A b s$ borehole to monitor the water qualities. Limited, additional sampling was made also particularly from:

(1) The uncontrolled discharge at Black Clough (BC) adit [NGR 386540 427320] itself, which has similar $\mathrm{pH}$ and alkalinity to Deerplay minewaters but higher $\mathrm{Fe}_{\text {tot }}$ concentration and a fluctuating chemistry. $B C$ samples are representative of the chemistries at the level of the natural decant point (outflow pathway for the mine system) at the surface for the water table in the (flooded) western mineworkings;

(2) A "low pH" surface discharge on site at Deerplay (DC) [NGR 387100 426500]: flow rate $441 / \mathrm{s} ; \mathrm{pH}$ 2.8-3.5; and high $\mathrm{Al}_{\text {tot }}$ (up to tens of $\mathrm{mg} / \mathrm{l}$ ) due to acid dissolution of aluminosilicates during drainage through colliery spoil on site (Banwart \& Malmström 2001; Nuttall et al. 2002b). DC samples are representative therefore of possible surficial or shallow-sourced (poor) water quality local to the site impacted by interactions with colliery spoil at the surface, and / or with shallow workings in or above the zone of water-table fluctuation which are still subject to ingress of air, supporting oxidation of pyrite (cf Younger 2000).

\section{Methodology}

Deerplay samples represent pumped minewaters from the $A b s$ Borehole in the western mineworkings collected during a continuous step-drawdown test. These "grab" samples were collected initially frequently (hourly) over the first few days, but then daily (metals, including total Fe, Mn and Al analyses) to weekly (major \& minor element cations and anions analyses) intervals during the continuous pumping schedule, and therefore generally represent instantaneous flux-averaged concentrations reflecting the zones of contribution (ZOCs) to the borehole and following the expanding zone of influence (ZOI) after initial removal of storage from the borehole. Certain samples from the $A b s$ Borehole (Samples A-H; Table 1) were subsequently analysed also for environmental isotopes: ${ }^{3} \mathrm{H},{ }^{14} \mathrm{C}$ (TDIC), $\delta^{2} \mathrm{H}, \delta 18 \mathrm{O}, \delta^{13} \mathrm{C}(\mathrm{TDIC})$, $\delta^{18} \mathrm{O}\left(\mathrm{SO}_{4}\right), \delta^{34} \mathrm{~S}\left(\mathrm{SO}_{4}\right)$. Sample A was taken prior to start of the pump testing, with samples $\mathrm{B}-\mathrm{H}$ then taken during the continuous pumping (stepped) test schedule. A few "grab" samples mainly for hydrochemical analyses (but including some isotopic analyses) were collected for characterisation and comparison particularly also from: diffuse (surficial) discharge on Deerplay Moor $(D C)$ and the Black Clough $(B C)$ adit discharge at the surface. Details of field and laboratory sampling and analytical protocols including for stable isotope samples are presented in SI-Methodology.

\section{Results}

Major/minor ion results for selected samples are presented in Table 2 along with their isotopic analyses (Tables 3a,b). Field sampling temperatures for the pumped Deerplay waters from the $A b s$ borehole initially increase over the first few days of pumping from c. $11^{\circ} \mathrm{C}$ to around $13^{\circ} \mathrm{C}(\mathrm{SI}-\mathrm{Fig} .3)$ when samples B-D were collected, but after these first few days of continuous pumping temperatures start to gradually decrease. The initial temperature rise over the first few days of pumping is matched also by an initial increase in observed electrical conductivity (taken as a proxy for Total Dissolved Solids (TDS) content; 
Fig. 2a) which seems to relate to a deeper water component being mixed in (see below); using a UK geothermal gradient of $\sim 26^{\circ} \mathrm{C} / \mathrm{km}$ suggests an average sampling depth at this stage nominally $\sim 75 \mathrm{~m}$ below the pump depth and encompassing therefore the intake water depth in the LM seam.

\section{Carbon systematics ( $p H$, alkalinity, $\delta^{13} \mathrm{C}$ )}

For the pumped Deerplay waters, Bicarbonate $\left(\mathrm{HCO}_{3}{ }^{-}\right)$Alkalinity concentrations initially rise from 367 $\mathrm{mg} / \mathrm{l}$ to $\sim 450 \mathrm{mg} / \mathrm{l}$ over the first few days of pumping, but then decline gradually over the rest of the pumping schedule reaching values towards $320 \mathrm{mg} / 1$ by end of test $(01 / 09)$. $\mathrm{HCO}_{3}{ }^{-}$generally is below detection in $D C$ waters, but $\sim 315 \mathrm{mg} / \mathrm{l}$ in the $B C$ waters. $\mathrm{pH}$ values in the waters abstracted from Deerplay start at a $\mathrm{pH} \sim 7$, reducing only gradually to $\mathrm{pH} \sim 6.6$ over the course of test pumping such that the waters remain essentially circum-neutral. The sampled $B C$ (adit) water also is circum-neutral ( $\mathrm{pH} \sim 6.9$ ). There is abundant acid-neutralising capacity in the carbonate minerals associated with sediments surrounding the Coal Measures. $D C$ surface discharge through the colliery spoil on site at Deerplay however shows the most acidic waters ( $\mathrm{pH} 2.83-3.51)$.

$\delta^{13} \mathrm{C}$ signatures range from -6.58 to $-8.8 \%$ (bulk) and $-5.4 \%$ to $-8.9 \%$ (specific) for the $A b s$ waters are isotopically heavier than UK soil atmosphere $\mathrm{CO}_{2}$ values which typically range over $-27 \pm 7 \%$ o (averaging $26.1 \pm 0.3 \%$ ) for temperate climate (Calvin cycle) respiration (Smith et al., 1976), again suggesting the effects water-rock interaction (cf. Scott et al., 1996). The $B C$ discharge yielded a heavier value of $-4.28 \%$ (bulk) but a lighter $-13.3 \%$ (specific).

\section{Conservative mixing indicators $(\mathrm{Cl}$, stable isotopes of water):}

Since the chloride $\left(\mathrm{Cl}^{-}\right)$ion geochemically tends to act conservatively in most subsurface waters, concentrations generally can be used as a tracer of water mixing within groundwaters. $\mathrm{Cl}^{-}$concentrations in the $A b s$ waters at start of pumping and over the first few days of pumping (10/07-13/07) are $\sim 15 \mathrm{mg} / 1 . \mathrm{Cl}^{-}$ concentrations then increase over the following fortnight of pumping more or less up to end of Step 2, reaching $\sim 215 \mathrm{mg} / 1$ (30/07; Fig.2b). Subsequently these peak $\mathrm{Cl}^{-}$concentrations more or less continually decrease over the rest of the course of the pumping test (Fig.2b). By contrast pumped sulfate $\left(\mathrm{SO}_{4}{ }^{2-}\right)$ concentrations show more or less a continual increase over the full period of step testing (Fig. 2b).

The initial trend in the isotope samples for $\delta^{18} \mathrm{O}\left(\mathrm{H}_{2} \mathrm{O}\right)$ signatures over the first few days of pumping is a shift from $-6.7 \%$ for sample A (taken before the pumping test started) to isotopically lighter values around $-7.0 \%$ for Samples B-D (Table 3a). The lightest isotopic signatures of -7.2 and $-7.1 \%$ are associated with Samples E and F, respectively, taken more or less at start and end of the period of increasing $\mathrm{Cl}^{-}$ concentration (Step 2). Samples $\mathrm{G}$ and $\mathrm{H}$ subsequently recordheavier values of $-6.7 \%$, alongside lower $\mathrm{Cl}^{-}$ concentrations. $\delta^{2} \mathrm{H}\left(\mathrm{H}_{2} \mathrm{O}\right)$ values trend generally from relatively isotopically heaviest value $-46.5 \% 0$ (Sample A) to the lightest value of $-49.9 \%$ (Sample G) over the course of pumping. Surface discharge samples $(B C \& D C)$ record values of $-6.6 \%$ in $\delta^{18} \mathrm{O}\left(\mathrm{H}_{2} \mathrm{O}\right)$, and $-46.7 \%$ and $-46.6 \%$ in $\delta^{2} \mathrm{H}_{(}\left(\mathrm{H}_{2} \mathrm{O}\right)$, respectively (Table 3a).

Redox Indicators ( $\left.\mathrm{DO}, \mathrm{Eh}, \mathrm{NO}_{3}, \mathrm{Fe}, \mathrm{Mn}\right)$ :

A dissolved oxygen (DO) measurement taken at the start of the pumping test recorded a low value (3.09 $\mathrm{mgO}_{2} / 1 ; \sim 30 \%$ DO saturation). The first three days of pumping (Samples B-D) show Eh values in the range -13 to $-109 \mathrm{mV}$. A single sample of $-73 \mathrm{mV}$ (26/07; Sample F) suggests that reducing conditions persist throughout Steps $1 \& 2$ of pumping. Only two further Eh measurements then are recorded subsequent to Step 2 when $\mathrm{Cl}^{-}$concentrations reduce, both of which show more oxidising values of $+33 \mathrm{mV}(02 / 08$; Sample G) and $+16 \mathrm{mV}(30 / 08$; Sample H). $B C$ water sampled at the start of pumping shows an Eh of $57 \mathrm{mV}(12 / 07)$. $D C$ samples show oxidising values in the range +226 to $+316 \mathrm{mV}$ over the course of the pumping test. Nitrate $\left(\mathrm{NO}_{3}{ }^{-}\right)$concentrations in the abstracted (pumped) Deerplay waters remain low $(\sim 1$ $\mathrm{mg} / \mathrm{l}$ ) throughout the pumping test. 
$\mathrm{Fe}_{\text {tot }}$ concentrations at start of pumping are c. $17.9 \mathrm{mg} / \mathrm{l}$. This value initially dips over the first few days of pumping (when samples B-D were collected), but then more or less continually increases up to c.33.2 $\mathrm{mg} / \mathrm{l}$ by end of test. A similar phenomenon of a dip in $\mathrm{Fe}_{\text {tot }}$ concentrations as the stratification breaks down initially in a pumped borehole also was identified in the abandoned Frances Colliery (Elliot \& Younger 2007). Subsequently, there are however two apparent changes in slope during further pumping with increasing $\mathrm{Fe}_{\text {tot }}$ concentrations at Deerplay, around 19/07 when the slope gets slightly steeper (cf. Sample E) and a more pronounced break around 30/07-02/08 when the $\mathrm{Cl}^{-}$concentration starts to decrease with still increasing $\mathrm{Fe}_{\text {tot }}$ but at a more gradual rate to a final level of c.33.2mg/l (04/09). Fe(II) concentrations mimic this trend in dissolved iron (Fig.2c) as does $\mathrm{Mn}_{\text {tot }}$ values (SI - FIGURE S4). Thus, significant levels of both $\mathrm{Fe}_{\text {tot }}$ (and $\mathrm{Mn}_{\text {tot }}$ ) remain at the end of test even as $\mathrm{Cl}^{-}$concentration decreases.

\section{Sulfur systematics $\left(\mathrm{SO}_{4}, \delta^{34} \mathrm{~S}\left(\mathrm{SO}_{4}\right), \delta^{18} \mathrm{O}\left(\mathrm{SO}_{4}\right)\right)$ :}

Dissolved $\mathrm{SO}_{4}{ }^{2-}$ concentrations (Fig. 2b) start $\sim 200 \mathrm{mg} / 1$ and increase to $\sim 370 \mathrm{mg} / 1$ mimicking the trend in $\mathrm{Fe}_{\text {tot }}$ and clearly showing the break of slope around 30/07 at the end of Step 2 (Fig.2c). As for Fetot, values continue to increase gradually after Step 2 as the $\mathrm{Cl}^{-}$concentrations decrease. $\mathrm{SO}_{4}{ }^{2-}$ concentrations are $\sim 350-370 \mathrm{mg} / 1$ in the $B C$ adit surface discharge samples; higher levels $(\sim 1000 \mathrm{mg} / 1)$ are recorded in $D C$ surface discharge samples. The $\delta^{34} \mathrm{~S}$ signature of the dissolved sulfate typically reflects the source sulfide, since oxidation characteristically shows little isotope fractionation during aerobic pathways of oxidation (although anaerobic pathways, eg via Fe(III) oxidation, might cause fractionation; Balci et al. 2007, 2012). For the $A b s$ borehole waters $\delta^{34} \mathrm{~S}\left(\mathrm{SO}_{4}\right)$ values apparently continuously decrease during pumping from $+8.20 \%$ (isotopically heavy; Sample A) to $-3.26 \%$ (isotopically light; Sample H). Both surface discharge samples are isotopically lighter again at $-5.85 \%$ o $(B C)$ and $-4.05 \%$ o $(D C)$ (Table $3 a$ ). $\delta^{18} \mathrm{O}\left(\mathrm{SO}_{4}\right)$ values are relatively constant at $\sim+10 \%$ for Samples A-D but then show isotopically lighter signatures for Samples E (+7.7\%o) and F (+8.9\%o) towards the end of Step 2; the single DC discharge sample shows a value of $+0.9 \%$ (Table $3 \mathrm{a}$ ). Oxygen isotope fractionation $\left[\Delta^{18} \mathrm{O}_{\mathrm{SO}-\mathrm{H} 2 \mathrm{O}}=\delta^{18} \mathrm{O}\left(\mathrm{SO}_{4}\right)-\right.$ $\delta^{18} \mathrm{O}\left(\mathrm{H}_{2} \mathrm{O}\right)$ ] between dissolved sulfate and water is generally characteristic of the potential oxidation processes for reduced sulfur species (Taylor and Wheeler, 1994). For the Deerplay waters all of the Samples A-D taken during Step 1 of pumping (Fig. 2d) show $\Delta^{18} \mathrm{O}_{\text {SO4-H2O }}$ signatures range between +16.6 and $+17.1 \%$, all significantly different from the $D C$ surficial discharge water sample $\left(\Delta^{18} \mathrm{O}_{\mathrm{SO}-\mathrm{H} 2 \mathrm{O}}=\right.$ $+7.5 \%$ ) but with Samples E and F (Step 2) displaying the lowest values in the range $(+14.9$ and $+16.0 \%$, respectively).

Age indicators $\left({ }^{3} \mathrm{H},{ }^{14} \mathrm{C}\right)$ :

Tritium $\left({ }^{3} \mathrm{H}\right)$ activities of 11.1 -12.6 TU generally for Samples A-F (Steps 1 \& 2; Table 3b); the $B C$ discharge sample also shows an activity of $12.2 \mathrm{TU}$ highlighting the possible hydraulic connection. A possible slight dip is seen for Sample C (10.3 TU) as deeper waters apparently are mixed in the borehole, and similar activities ( $10 \mathrm{TU})$ are seen subsequently also in later Samples G and H. Modern rainfall at the time of sampling was characterized by TU value of just 2.87-3.63 TU (cf. date for 1998 to 2003 reported by the IAEA/WMO Global Network of Isotopes in Precipitation (GNIP) data for the nearest measurement point to our site, i.e. Valentia Observatory: Station 395300, Ireland, Lat. 51 ${ }^{\circ} 55^{\prime} 48^{\prime \prime}$, Long. $-10^{\circ} 15^{\prime} 00^{\prime \prime}$, Altitude, 9m). Given an activity $~ 65$ TU in rainfall in the late 1960's/early 1970's around the time the Deerplay Mine was closed and accounting for its half-life $\left(\tau_{1 / 2}=12.43\right.$ years $)$, the observed ${ }^{3} \mathrm{H}$ activities of 11 to $12.6 \mathrm{TU}$ at Deerplay could conceivably reflect a still predominant signature of rainfall recharged around the time of mine abandonment. Raw groundwater ages (estimated based simply on applying the radioactive decay law to an initial activity of $100 \mathrm{pmc}$ - per cent modern carbon with $\tau_{1 / 2}=5730$ years) for sample ${ }^{14} \mathrm{C}$ activities all around $25 \mathrm{pmc}$ suggest apparent residence times $\sim 11000$ years for both $A b s$ waters and the $\mathrm{BC}$ discharge. However this is clearly at odds with a relatively shallow circulation system and the presence of ${ }^{3} \mathrm{H}$ in the waters and suggests a predominating effect of imprinting and dilution of the dissolved C-14 signatures by "dead" carbon sources, which would imply that qualitatively the water ages 
are all modern. However, possible gas dissolution effects (cf. Elliot \& Younger 2007) on C-isotope systematics during sampling have not been quantified nor a clear discriminating ${ }^{13} \mathrm{C}$-model applied to date the waters further.

\section{Discussion}

Evolution of isotopic signatures during pumping

On a genetic $\delta^{18} \mathrm{O}-\delta^{2} \mathrm{H}$ plot, sample A (taken before pumping started) plots initially close to the values of $B C$ and $D C$, which are surface water discharges; all three samples lie below the Global Meteoric Water Line (GMWL; Fig.3). Both $B C$ (adit) and $D C$ (discharge) surface water samples have been exposed to the atmosphere such that their isotopic signatures suggest an evaporative character. It is thus possible that Sample A reflects shallow-sourced recharge waters at the top of the stratified water column in the borehole, that have infiltrated from the surface preserving an evaporation signature. Over the first few days of pumping there was a shift to isotopically lighter values, plotting much closer to the GMWL (Samples BD; Fig. 3). Samples E-F taken during the period of increasing $\mathrm{Cl}^{-}$concentration show water isotopic signatures which lie on the GMWL (Fig. 3). Samples $\mathrm{G}$ and $\mathrm{H}$ (as $\mathrm{Cl}^{-}$concentrations decrease) subsequently record heavier isotopic values plotting away from the GMWL again and mixing in of an evaporative character end-member. Thus, Samples B-D in line with initial trends in sampling temperature and electrical conductivity, initial trends during pumping implicate mixing of the chemical quality of the initially stratified water column in the Deerplay $A b s$ borehole over the first few days of test pumping, showing a mixing in of deeper waters in the borehole shaft with overlying shallower waters. Similar initial breakdown of stratification and mixing effects have been observed during continuous pumping of the abstraction borehole shaft at the flooded Frances Colliery in more complex workings (Nuttall \& Younger 2004; Elliot \& Younger 2007). Subsequently pumped water samples (Samples E-H) apparently reflect the mixing-in to the $A b s$ borehole of waters from the expanding zone of influence (ZOI) following this initial removal of storage from the borehole (Samples B-D).

\section{Geochemical affinities}

In a coal mine environment, sulfate to chloride ratios tend to reveal the relative dominance of pyrite oxidation (which occurs only under aerobic conditions, typically in or above the zone of water table fluctuation) versus contributions from deep-seated, brackish to saline groundwaters typical of the deep coal-bearing strata in their unmined state (Younger 1998). A cross-plot of dissolved sulfate against $\mathrm{Cl}^{-}$ concentration for the particular samples collected for isotopic analyses (Fig.4) shows Sample D plotting slightly higher than the earlier waters (samples $\mathrm{B}, \mathrm{C}$ ), indicating a somewhat enhanced $\mathrm{SO}_{4} / \mathrm{Cl}$ ratio. Subsequently Sample E (19/07), taken just after the start of Step 2 of pumping, also plots somewhat towards the Black Clough ( $B C$, adit) ratio with Sample F (near the end of Step 2) showing a ratio close to that of $B C$, highlighting that as a possible admixing end-member at this stage of pumping. This is consistent with the hydraulic evidence, which shows (SI - Fig.S1) that the $B C$ adit discharge ceased on $17 / 07$, after which waters in that vicinity were drawn back towards the $A b s$ borehole. This is supported also in chloride-correlation plots of other hydrochemistries following the trend of increasing $\mathrm{Cl}^{-}$concentrations (SI - Fig.S5). Given this interpretation, it is not surprising that samples $\mathrm{G}$ and $\mathrm{H}$ then plot between $B C$ and $D C$ signatures (Fig.4).

\section{Sulfate sources}

The principal source of dissolved sulfate in is likely from the oxidation of sulfides, since during active colliery operations (ie prior to closure and abandonment) dewatering of the mineworkings necessarily exposed chemically-reduced sulfides (eg the monosulfide, $\mathrm{FeS}$, and also pyrite, $\mathrm{FeS}_{2}$ ) to ingress of $\mathrm{O}_{2}$ in air over a period of decades. This would give rise to a veneer of highly soluble (effloresecent) oxidised products and dissolved $\mathrm{Fe}$ and $\mathrm{SO}_{4}$ loadings to the water quality (see SI-Mineral Saturation Indices). On a genetic cross-plot for dissolved sulfate (Fig.5), the $\delta^{34} \mathrm{~S}_{\left(\mathrm{SO}_{4}\right)}$ range of the Deerplay pumped samples is 
typical of sulfate derived from the oxidation of reduced inorganic sulfur compounds (cf. Krouse \& Mayer 2000, their Fig. 7.3). The pre-test Sample A shows the heaviest signature (+8.2\%o), with samples B-D all showing values around $+5 \%$ o (reflecting initial mixing of waters in the borehole), before signatures shift further to lighter isotopic values during later pumping (see below). For $\delta^{18} \mathrm{O}\left(\mathrm{SO}_{4}\right)$, however, the $A b s$ waters apparently plot with significantly heavier isotopic signatures than is typical for sulfate derived from oxidation of reduced inorganic sulfur compounds (Krouse \& Mayer 2000, their Fig.7.3). This may, however, reflect the sulfur content of the coals at Deerplay, since low-sulfate coals show heavier $\delta^{18} \mathrm{O}\left(\mathrm{SO}_{4}\right)$ signatures (McCarthy et al., 1998) reflecting a higher proportion of primary oxidation signature (oxidation of sulfides by molecular $\mathrm{O}_{2}$ ) over secondary oxidation signature (oxidation of sulfides by water via some other oxidising agent) (see SI-Sulfur isotope systematics). Banwart \& Malmström (2001) cite a typical value $\sim 0.3 \mathrm{wt} \% \mathrm{~S}$ (pyrite) content for the Black Clough Mine in the LM seam, below the generic threshold of $0.5 \% \mathrm{~S}$ for significant acid-generating potential (Younger et al. 2001). The pumped Deerplay waters comparatively also show maximal $\mathrm{Fe}_{\text {tot }}$ and $\mathrm{SO}_{4}$ concentrations an order of magnitude less than seen eg for the Frances Colliery (Scotland) with its higher associated sulfur content $(2.75 \%)$ in coal seams generating $\mathrm{pH} \sim 5$ (Elliot \& Younger 2007). For the Deerplay $A b s$ waters, the calculated proportion of primary oxidation component in the $\delta^{18} \mathrm{O}\left(\mathrm{SO}_{4}\right)$ signatures generally is greater than two-thirds, with the Samples $\mathrm{E}$ and $\mathrm{F}$ associated with the lower end of this range; the surface discharge $D C$ sample is characterised particularly as showing instead a two-thirds proportion of secondary weathering (see SISulfur isotope systematics).

\section{Mixing patterns}

The sources of mixing implicated in the patterns of dissolved sulfate developed during pumping of the $A b s$ borehole are characterised in Fig.6. Following mixing of a deeper (denser) water component in the borehole itself (Samples B-D; Figs. 6a,c), Sample E plots slightly towards Sample DC (Figs.6a,c) reflecting an admixture also of a shallower water likely affected by drainage impacted apparently by surface colliery spoil material and / or oxidation in shallow, aerated workings. Subsequently Sample F plots much closer to Sample $B C$ as a possible end-member of mixing (Fig.6a) reflecting the draw-back to the pump of drainage water which had previously been migrating towards the surface outflow at Black Clough adit, as identified above. This source is associated also with the increasing $\mathrm{Cl}^{-}$concentration (Fig.2b) during Step 2 of pumping and is in line with a representative source $B C$ adit discharge sample generally showing also relatively high $\mathrm{Cl}^{-}$contents. Although $\delta^{18} \mathrm{O}\left(\mathrm{SO}_{4}\right)$ was not actually measured for the $\mathrm{BC}$ (adit) water, if Sample $\mathrm{F}$ reflects predominantly a $B C$ component then its $\Delta^{18} \mathrm{O}_{\mathrm{SO} 4-\mathrm{H} 2 \mathrm{O}}$ signature of $+16.0 \%$ and using the $\delta^{18} \mathrm{O}\left(\mathrm{H}_{2} \mathrm{O}\right)$ for $B C$ (Table 3a) would suggest a value of $\delta^{18} \mathrm{O}\left(\mathrm{SO}_{4}\right) \cong+9 \%$ for the $B C$ representative end-member. Similarly, the more or less flat trend towards Sample F (Fig. 6c) would suggest a value of the order +8 to $+9 \%$ characterising this $B C$ end-member of mixing for $\delta^{18} \mathrm{O}\left(\mathrm{SO}_{4}\right)$, again suggesting a predominant character of primary oxidation component in this sample (see SI-Sulfur isotope systematic). During Step 4 of the pumping test (Table 1) the water level in the Abstraction Borehole falls below the level of the decant point from eastern to western workings (327.8 mAOD) and the water table gradient from eastern to western workings steepens (Fig.1c) such that the water qualities (Sample H) might reflect a mixing-in of some waters from the eastern workings reflected also e.g. in the enhanced specific electrical conductivities observed (Fig. 2a). However, both Samples G and H plot (Fig.6a) back towards the $D C$ signature in $\delta^{34} \mathrm{~S}\left(\mathrm{SO}_{4}\right)$ suggesting that this source representatively characterises the predominating diluting end-member as $\mathrm{Cl}^{-}$concentrations decrease in the these later pumped waters. This is supported further in chloride-correlation plots of other hydrochemistries following the trend of decreasing $\mathrm{Cl}^{-}$ concentrations (SI-Fig.5). Simple mixing calculations (using eg the NETPATH model, data not shown, Plummer et al., 1994) based on two-component mixing of $\mathrm{Cl}^{-}$concentrations using Sample $\mathrm{F}$ and $D C$ as representative end-members suggest that at this point in time $82 \%$ of the water quality signature of Sample $\mathrm{G}$ comes from a shallow surficial source, such as oxidation in shallow workings or weathering of colliery 
spoil material. This is strongly implicated, for instance, during Step 4 of pumping. The later samples (G \& $\mathrm{H})$ exhibit light $\delta^{34} \mathrm{~S}\left(\mathrm{SO}_{4}\right)$ values akin to both $D C$ and $B C$ samples (Table 3a); moreover, the more oxidising redox (Eh) signatures seen in these two later samples ( $\mathrm{G}$ and $\mathrm{H})$ also tie in with the observed strongly oxidising signature characterizing the $D C$ sample (Table 2), whereas the $B C$ samples are generally reducing in character.

Finally, the water quality mixing trends seen in Samples B-D appear to reflect interplay of deep and shallow sources of water. While it might be anticipated that waters with high $\mathrm{SO}_{4} / \mathrm{Cl}$ ratios are likely to represent renewed pyrite oxidation in recently dewatered workings being invaded by air, these would be expected to have tritium contents similar to modern air (i.e. 2.87-3.63 TU); in contrast, our data show that a substantial component of the waters with pyrite oxidation affinities have much higher tritium contents $(11-12 \mathrm{TU})$. This suggests that stratification of groundwater within the old workings during the initial flooding of the workings in the 1960s, which would have involved dissolution of efflorescent pyrite oxidation salts in the previously ventilated workings (cf Younger 1997, 2000; Gyzl \& Banks, 2007), led to ponding of some of the more contaminated waters at depth, below the effective depth of bulk advection under natural post-rebound flow conditions. The onset of pumping disturbed these deeper stratified waters, allowing recovery of sulfate arising during the original rebound of waters through the Deerplay workings several decades before the pumping test. This is the first time such a phenomenon has been characterised isotopically. Plotting the sulfur isotopic signatures versus the fraction $(m)$ derived from secondary oxidation sources (Figs. 6b,d) extrapolation back to the origin $(\mathrm{m}=0)$ then suggests $\delta^{34} \mathrm{~S}(\mathrm{SO} 4) \cong-1.6 \%$ o and $\delta^{18} \mathrm{O}\left(\mathrm{SO}_{4}\right) \cong+15 \%$ or for 'first flush' signature affected by primary oxidation. As for the $A b s$ samples, the relatively isotopically heavier $\delta^{18} \mathrm{O}\left(\mathrm{SO}_{4}\right)$ than is usually considered representative for oxidation of reduced inorganic sulfur compounds could be associated with coal of lower sulfate content. A similar primary oxidation signature for sulfate pyrite by $\mathrm{O}_{2}$ was suggested initially in pumping the flooded, abandoned Frances Colliery (Scotland; Elliot \& Younger, 2007) - but there mixing in the hydraulically more complex system occurred in a matter of just hours (not days), borehole mixing was not isotopically well-characterised and was almost immediately swamped by signatures attributed to induced leakage of waters from faulty surface lagoons.

\section{Conclusions}

The flooded mineworkings at Deerplay represent a quasi-karstic aquifer system which is of sufficient simplicity to allow confident identification of sources of different components of the groundwater body and their dynamic mixing induced by pumping. The pumped Deerplay water qualities are dominated by processes of relatively rapid mixing and / or dynamic draw-in to the $A b s$ borehole of a range source waters. The use of environmental tracers, integrated with dissolved hydrochemistries, and placed within its hydraulic setting, has allowed the dynamics and mixing of water qualities into the $A b s$ borehole to be followed as the western workings of the abandoned mine at Deerplay (Lancashire) were pumped. Continuous pumping of the rebound waters in the flooded Deerplay mine show an initial breakdown of the stratification of water qualities within the borehole itself and within days of the start of test. Sulfur isotopic signatures (Samples B-D) here show the strongest signatures of pyrite oxidation by molecular $\mathrm{O}_{2}$, and extrapolation of their mixing trend potentially identifies predominant signatures $\left(\delta^{34} \mathrm{~S}\left(\mathrm{SO}_{4}\right) \cong-1.6 \%\right.$, $\delta^{18} \mathrm{O}\left(\mathrm{SO}_{4}\right) \cong+15 \%$ ) emplaced from a vestigial, 'first flush' phenomenon in this mine. Sample $\mathrm{E}$ particularly reflects a (deeper) water signature unaffected by evaporation but mixed with a water quality $\left(\mathrm{SO}_{4}{ }^{2-}\right)$ impacted by shallower system waters. Following initial mixing in the borehole itself, breakdown of stratification, and removal of the water storage component from the $A b s$ borehole, subsequent water quality evolution then reflects the expanding zones of contribution to the pumped waters. After a week of pumping the Black Clough adit discharge $(B C)$ had ceased as water levels in the system were brought below its decant level (332.5 mAOD). Increasing $\mathrm{Cl}^{-}$concentration along with sulfate and heavy metals (eg $\mathrm{Fe}_{\mathrm{tot}}$ ) loadings are identified by $\delta^{34} \mathrm{~S}_{\left(\mathrm{SO}_{4}\right)}$ ) signatures (Sample $\mathrm{F}$ ) as reflecting waters at the level of the adit (represented by $B C$ ) drawing back to and mixing with the $A b s$ borehole. Subsequently, as the borehole 
waters are abstracted further it appears that a high-sulfate, but low chloride concentration shallow-sourced recharge is induced from on-site (characterised by $\delta^{34} \mathrm{~S}\left(\mathrm{SO}_{4}\right)$ signatures for pumped Samples $\mathrm{G} \& \mathrm{H}$ in comparison to the $D C$ sample signature (taken as representative of local waters apparently impacted by water-rock interaction with colliery spoil at the surface) as the water levels in the $A b s$ Borehole are lowered from 332.12 to $329.72 \mathrm{mAOD}$ and beyond.

Within the context of developing a pump-and-treat solution for polluted groundwaters (cf US EPA 1996), the application of environmental tracers reveals some of the potential pitfalls that may occur as drawdown induces upward migration of deeper, more polluted water, and / or renewed oxidation in newly dewatered zones. These findings reflect those found in another aquifer context by Brown et al. (2002). Overall, the lesson is clear: where investigations are taking place in groundwater systems in which mixing is a potentially important process, the addition of even modest amounts of additional sampling and analysis for isotopic environmental tracers can greatly expand understanding of the flow and geochemical dynamics of pumped groundwater systems.

\section{Supporting Information}

Additional Supporting Information (SI) may be found in the online version of this article:

9 pages of text covering the background to the Deerplay mineworkings; the hydraulic context of the test pumping of the $A b s$ borehole; the methodologies for sample analyses [field methods, major \& minor element cations \& anions, $\left.{ }^{3} \mathrm{H},{ }^{14} \mathrm{C}(\mathrm{TDIC}), \delta^{2} \mathrm{H}, \delta 18 \mathrm{O}, \delta^{13} \mathrm{C}(\mathrm{TDIC}), \delta^{18} \mathrm{O}\left(\mathrm{SO}_{4}\right), \delta^{34} \mathrm{~S}\left(\mathrm{SO}_{4}\right)\right]$; supporting results on calculations for mineral saturation indices; and the proportions of primary vs. secondary weathering in sulfide oxidation based on sulfur isotope systematics. Figs S1-S5. Tables S1, S2.

Acknowledgements: This work was funded by an Urgency Grant (GR3/13205) from the UK Natural Environment Research Council (NERC). Thanks go to: the Coal Authority (UK) for providing access to their Deerplay site and providing logistical support during our sampling work; to Dr. Charlotte Nuttall (then at University of Newcastle) for collecting water samples and providing IC and ICP-MS (cation) results; Angela Downey (sample precipitations for ${ }^{14} \mathrm{C}$ and sulfur isotopes; $\delta^{18} \mathrm{O}, \delta^{2} \mathrm{H}$ of water analyses, specific $\delta^{13} \mathrm{C}$ and $\mathrm{HS}^{-}$analyses), Dr. Neil Ogle $\left(\mathrm{CO}_{2}\right.$ gas preparation for ${ }^{14} \mathrm{C}$ analyses and bulk $\delta^{13} \mathrm{C}$ analyses) and Mike Matiasek (IC anions) of the QUB EERC; John Morrison (Micromass, UK) for sulfate isotopic $\left(\delta^{18} \mathrm{O}, \delta^{34} \mathrm{~S}\right)$ analyses; Dr. Christopher J. Eastoe for ${ }^{3} \mathrm{H}$ analyses (Laboratory of Isotope Geosciences, University of Arizona, USA; see www.geo.arizona.edu/researchers/mbaker/AustinLong/); and Dr. A.J. Timothy Jull for ${ }^{14} \mathrm{C}$ analyses (NSF Accelerator Mass Spectrometry Group, University of Arizona, USA; see/www.physics.arizona.edu/ams/). The IAEA/WMO GNIP database can be accessed via $w w w$-naweb.iaea.org/napc/ih/index.html. The authors thank three anonymous reviewers and the journal editor for their helpful and insightful comments on this article.

\section{References}

Ahmad M, Tasneem MA, Rafiq M, Khan IH, Faroog M, Sajjad MI (2003) Interwell tracing by environmental isotopes at Fimkassat Oilfield, Pakistan. Applied Radiation and Isotopes, 58: 611-619.

Bailey M, Watson I, Wyatt L, Davies T (2011) Applications of pumping tests in the development of mine water management strategies and remediation schemes. In: TR Rüde, A Freund \& Ch Wolkersdorfer (Eds.) Proceedings of the 11th International Mine Water Association Congress (IMWA 2011) - "Mine Water - Managing the Challenges", Aachen, Germany 2011. pp.97-100.

Balci N, Shanks WC, Mayer B, Mandernack KW (2007) Oxygen and sulfur isotope systematics of sulfate produced by bacterial and abiotic oxidation of pyrite. Geochimica Cosmochimica Acta 71: 3796-3811.

Balci N, Mayer B, Shanks WC, Mandernack KW (2012) Oxygen and sulfur isotope systematics of sulfate 
produced during abiotic and bacterial oxidation of sphalerite and elemental sulfur. Geochimica Cosmochimica Acta 77: 335-351.

Banwart SA, Malmström ME (2001) Hydrochemical modelling for preliminary assessment of minewater pollution. Journal of Geochemical Exploration 74: 73-97.

Barnes TM (2000). Treatment of the gravity minewater discharge at Deerplay Mine, Burnley, UK. In: 7th International Mine Water Association Congress, Ustron, Poland 2000, IMWA 2000 Paper 31, pp.344351.

Brown CJ, Colabufo S, Coates JD (2002) Aquifer geochemistry and effects of pumping on ground-water quality at the Green Belt Parkway well field, Holbrook, Long Island, New York. U.S. Geological Survey, Water-Resources Investigations Report 01-4025, Coram, New York. 21pp.

Craig H (1961) Isotopic variations in meteoric waters. Science 133: 1702-1703.

Dansgaard W (1964) Stable isotopes in precipitation. Tellus 16: 436-468.

Domenico, PA, Schwartz, FW. (1997) Physical and Chemical Hydrogeology. (2nd ed). Wiley, New York, $528 \mathrm{pp}$.

Einarson MD, Cherry JA (2002) A new multi-level ground-water monitoring system utilizing multichannel tubing. Ground-Water Monitoring and Remediation, 22(4): 52-65.

Elschami F (1991) Water type variation during pumping test - Al Jaww Plain southeast of Al-Ain in the United Arab Emirates. GeoJournal, 24(4): 383-386.

Elliot T, Younger PL (2007) Hydrochemical and isotopic tracing of mixing dynamics and water quality evolution under pumping conditions in the mine shaft of the abandoned Frances Colliery, Scotland. Applied Geochemistry 22(12): 2834-2860.

Faure G., Mensing TM (2005) Chapter 16 Mixing theory. In: Isotopes. Principles and Applications. Third Edition, John Wiley, New jersey, USA. pp.347-361.

Gzyl G, Banks D (2007) Verification of the "first flush" phenomenon in mine water from coal mines in The Upper Silesian Coal Basin, Poland. Journal of Contaminant Hydrology, 92: 66-86.

IMC Consulting Engineers (2000) Report on the Test Pumping for Minewater Control at Deerplay, Lancashire. Coal Authority Report, Mansfield, Nottinghamshire, UK. D3621/U. 31pp., 29 Figs., 5 Tables, 12 Plates, + 5 Appendices: "WRA 1991 Section 32 Application \& Water Features Survey"; "Geological borehole Logs"; "Rainfall Data"; "Water Quality Analyses"; Groundwater Monitoring Data".

Johnson KL, Nuttall CA, Younger, PL (2004). Developing a predictive understanding of hydrological and hydrochemical changes in abandoned coalfields. Final Report for the Coal Authority, Hydrogeochemical Engineering Research \& Outreach (HERO), University of Newcastle Upon Tyne, UK. December 2004. 65pp. + Appendices.

Krouse HR, Mayer B (2000) Sulphur and oxygen isotopes in sulphate. In: P Cook, AL Herczeg (Eds.) Environmental Tracers in Subsurface Hydrology. Kluwer, Boston, USA. pp.195-231 (Chapter 7).

Mayo AL, Nielsen PJ, Loucks M, Brimhall WH (1992) The use of solute and isotopic chemistry to identify flow patterns and factors which limit Acid Mine Drainage in the Wasatch Range, Utah. Ground Water 30(2): 243-249

McCarthy MDB., Newton RJ, Bottrell SH (1998) Oxygen isotope compositions of sulfate from coals: implications for primary sulphate sources and secondary weathering processes. Fuel, 77(7): 677-682.

Mink LL, Williams RE, Wallace AT (1972) Effect of early day mining operations on present day water quality. Ground Water 10(1): 17-26.

Nuttall CA, Adams R, Younger PL (2002a) Integrated hydraulic-hydrogeochemical assessment of flooded Deep mine voids by test pumping at Deerplay (Lancashire) and Frances (Fife) Collieries. In: PL Younger \& NS Robins (Eds.) Mine Water Hydrogeology and Geochemistry, Geological Society, London, Special Publications 198. pp.315-326.

Nuttall CA, Adams R, Younger PL (2002b) Frances and Deerplay Colliery Report, University of Newcastle upon Tyne, UK. 36+pp. 
Nuttall CA, Younger PL (2004) Hydrochemical stratification in flooded underground mines: an overlooked pitfall. Journal of Contaminant Hydrology 69: 101-114.

Parry WT, Fortser CB, Solomon DK, James LP (2000) Ownership of mine-tunnel discharge. Ground Water 38(4): 487-496.

Plummer LN, Prestemon EC, Parkhurst D (1994) An interactive code (NETPATH) for modeling NET geochemical reactions along a flow PATH - Version 2.0. U.S. Geological Survey Water- Resources Investigations Report 94-4169, Reston, Virginia, USA. 134pp.

Sanford WE, Aeschbach-Hertig W, Herczeg AL (2011) Preface: Insights from environmental tracers in groundwater systems. Hydrogeology Journal, 19: 1-3.

Scott AC, Mattey DP, Howard R (1996) New data on the formation of Carboniferous coal balls. Review of Palaeobotany and Palynology 93: 317-331.

Smith DB, Downing RA, Otlet RA, Pearson FJ (1976) The age of groundwater in the Chalk of the London Basin, Water Resources Research, 12: 392-404.

Taylor BE, Wheeler MC (1994) Sulfur- and oxygen- isotope geochemistry of acid mine drainage in the Western United States: field and experimental studies revisited. In: CN Alpers, DW Blowes (Eds), Environmental Geochemistry of Sulfide Oxidation. American Chemical Society (ACS) Symposium Series 550, pp. 481-514.

Todd, D.K. (1980) Groundwater Hydrology. Wiley, New York. 535pp.

US EPA (1996) Pump-and-treat groundwater remediation: a guide for decision-makers and practitioners. US Environmental Protection Agency Office of Research and Development. Publicaiton EPA/625/R95/005/ Cincinnati, Ohio. 74pp.

Wilson, R.D., Thornton, S.F. \& Mackay, D.M. (2004). Challenges in monitoring the natural attenuation of spatially variable plumes. Biodegradation 15, 359-369.

Wireman M, Stover B (2011) Hard-rock mining and water resources. Ground Water 49(3): 310-316

Younger PL (1997) The longevity of minewater pollution: a basis for decision-making. Science of the Total Environment 194/195: 457-466.

Younger, PL (1998) Coalfield Abandonment: Geochemical Processes and Hydrochemical Products. In Nicholson, K., Energy and the Environment. Geochemistry of Fossil, Nuclear and Renewable Resources. Society for Environmental Geochemistry and Health. McGregor Science, Aberdeen. pp. 1 29.

Younger PL (2000) Predicting temporal changes in total iron concentrations in groundwaters flowing from abandoned deep mines: a first approximation. Journal of Contaminant Hydrology 44: 47-69.

Younger PL (2001) Mine water pollution in Scotland: nature, extent and preventative strategies. Science of the Total Environment 265: 309-326.

Younger, P.L., Banwart, S.A., and Hedin, R.S. (2002) Mine Water: Hydrology, Pollution, Remediation. Springer, Berlin. 464pp.

Zhou J, Sun J, Zhang F (1993) Origin of Mine Water by Using Environmental Isotope Techniques in Water-Logged Coal Mines, Pingdingshan, China. Mine Water and Environment 12: 63-69.

Ziegler W, Middleton H (2011) Analysis of mine water origins using geochemistry, Tritium isotopes and algae. In, T.R. Rüde, A. Freund \& Ch. Wolkersdorfer (Eds.) Proceedings of the 11th International Mine Water Association Congress (IMWA 2011) - "Mine Water - Managing the Challenges", Aachen, Germany 2011. pp.133-138. 


\section{List of Tables:}

Table 1 Summary of the stepped Test Pump data for the abstraction borehole at Deerplay Colliery. During this time water levels in the abstraction borehole were lowered by around $20 \mathrm{~m}$ (after IMC Consulting Engineers, 2000; Nuttall et al., 2002a,b). Also labelled are the specific isotope samples taken within each Step test period.

Table 2 Major \& minor ions - Deerplay waters (all values $\mathrm{mg} / \mathrm{L}$, except $\mathrm{pH}$ units). Ion analyses by Ion Chromatography (see SI-Methodology)

Table 3a $\mathrm{O}, \mathrm{H}, \mathrm{S}$ isotope systematics of $\mathrm{H}_{2} \mathrm{O}$ and $\mathrm{SO}_{4}$ - Deerplay waters. All $\delta$-values \%o against Vienna Standard Mean Ocean Water (VSMOW) or Canyon Diablo Troilite (CDT) standards. Standard Deviations $(\mathrm{SD})$ are on replicate $(\mathrm{N}=2)$ analyses.

Table $3 \mathbf{b}{ }^{3} \mathrm{H}$ and C-isotope systematics of TDIC - Deerplay waters. All $\delta$-values \%o versus Vienna Pee Dee Belemnite (VPDB) standard; ${ }^{3} \mathrm{H}$ activity in TU. Standard Deviations (SD) are on replicate $(\mathrm{N}=2)$ analyses excepting for TU and ${ }^{14} \mathrm{C}$ activities which are from (Poisson) counting errors. 


\begin{tabular}{|c|c|c|c|c|}
\hline Step & $\mathrm{Q}(1 / \mathrm{s})$ & Step Period & $\begin{array}{l}\text { Water Level in abstraction } \\
\text { borehole (m AOD) }\end{array}$ & Isotope samples \\
\hline 0 & & $\begin{array}{l}\text { Prior to continuous test pumping of } \\
\text { Abstraction Borehole }\end{array}$ & & $\mathrm{A}(09 / 07)$ \\
\hline 1 & 7.25 & $10 / 0713: 00-17 / 0713: 00$ & $333.29-332.12$ & $\begin{array}{l}\mathrm{B}(11 / 07)-\mathrm{D}(13 / 07) \\
+\mathrm{DC}, \mathrm{BC}\end{array}$ \\
\hline 2 & 15 & 17/07 13:00-31/07 13:00 & $332.12-329.72$ & $\mathrm{E}, \mathrm{F}$ \\
\hline 3 & 22 & $31 / 0713: 00-14 / 0812: 00$ & $329.72-327.52$ & $\mathrm{G}$ \\
\hline 4 & 30.5 & $14 / 0812: 00-18 / 0913: 00$ & $327.52-311.56$ & $\mathrm{H}$ \\
\hline
\end{tabular}

Table 1.

\begin{tabular}{|c|c|c|c|c|c|c|c|c|c|c|}
\hline $\begin{array}{c}\text { Sample } \\
\#\end{array}$ & Date & $\begin{array}{c}\text { Eh, } \\
\mathrm{mV}\end{array}$ & $\begin{array}{c}\mathrm{SEC}, \\
\mu \mathrm{S} / \mathrm{cm} \\
\left(25^{\circ} \mathrm{C}\right)\end{array}$ & $\begin{array}{c}\text { Field } \\
\mathrm{pH}\end{array}$ & $\begin{array}{c}\text { Field } \\
\mathrm{HCO}_{3}\end{array}$ & $\mathrm{Cl}$ & $\mathrm{SO}_{4}$ & $\mathrm{NO}_{3}$ & $\mathrm{~F}$ & $\mathrm{HS}$ \\
\hline $\mathrm{A}^{*}$ & $09 / 07 / 2000$ & n.d. & n.d. & n.d. & n.d. & 15 & 244 & 1.07 & 0.78 & 0.008 \\
\hline $\mathrm{B}$ & $11 / 07 / 2000$ & -69 & 1032 & 6.96 & 368 & 15 & 218 & 1.23 & 0.76 & 0.029 \\
\hline $\mathrm{C}$ & $12 / 07 / 2000$ & -63 & 1060 & 7.07 & 397 & 14 & 237 & 1.21 & 0.77 & 0.004 \\
\hline $\mathrm{D}$ & $13 / 07 / 2000$ & -61 & 1071 & 7.16 & 444 & 14 & 293 & 0.96 & 0.78 & 0.053 \\
\hline $\mathrm{E}$ & $19 / 07 / 2000$ & n.d. & 1118 & 6.69 & 385 & 27 & 314 & 2.34 & 0.70 & 0.006 \\
\hline $\mathrm{F}$ & $26 / 07 / 2000$ & -73 & 1184 & 6.88 & 378 & 136 & 137 & 1.40 & 0.77 & 0.006 \\
\hline $\mathrm{G}$ & $02 / 08 / 2000$ & 33 & 1231 & 7.08 & 389 & 55 & 360 & 1.34 & 0.74 & 0.004 \\
\hline $\mathrm{H}$ & $30 / 08 / 2000$ & 16 & 1225 & 7.02 & 397 & 53 & 318 & 1.31 & 0.75 & 0.005 \\
\hline $\mathrm{DC}$ & $12 / 07 / 2000$ & 283 & 2071 & 3.07 & 0 & 38 & 1615 & 1.27 & 0.00 & 0.002 \\
\hline $\mathrm{BC}$ & $12 / 07 / 2000$ & -57 & 1194 & 6.9 & 313 & 164 & 148 & 1.50 & 3.55 & 0.018 \\
\hline
\end{tabular}

n.d. - not determined

* Sampled prior to start of pumping test

Table 2. 


\begin{tabular}{|c|c|c|c|c|c|c|c|c|c|}
\hline Sample \# & Date & $\begin{array}{c}\delta^{18} \mathrm{O} \\
(\mathrm{VSMOW})\end{array}$ & $\begin{array}{c}+/- \\
(\mathrm{SD})\end{array}$ & $\begin{array}{c}\delta^{2} \mathrm{H} \\
\text { (VSMOW) }\end{array}$ & $\begin{array}{c}+/- \\
(1 \mathrm{SD})\end{array}$ & $\begin{array}{c}\delta^{18} \mathrm{O}\left(\mathrm{SO}_{4}\right) \\
(\mathrm{VSMOW})\end{array}$ & $\begin{array}{c}+/- \\
(1 \mathrm{SD})\end{array}$ & $\begin{array}{c}\delta^{34} \mathrm{~S}_{\left(\mathrm{SO}_{4}\right)} \\
(\mathrm{CDT})\end{array}$ & $\begin{array}{c}+/- \\
(1 \mathrm{SD})\end{array}$ \\
\hline $\mathrm{A}^{*}$ & $09 / 07 / 2000$ & -6.7 & 0.1 & -46.5 & 0.49 & 9.9 & 0.1 & 8.20 & 0.14 \\
\hline $\mathrm{B}$ & $11 / 07 / 2000$ & -7.0 & 0.0 & -47.2 & 0.33 & 9.8 & 0.1 & 5.74 & 0.18 \\
\hline $\mathrm{C}$ & $12 / 07 / 2000$ & -6.9 & 0.1 & -47.3 & 0.42 & 10.2 & 0.1 & 5.11 & 0.47 \\
\hline $\mathrm{D}$ & $13 / 07 / 2000$ & -7.0 & 0.0 & -46.7 & 0.35 & 10.1 & 0.1 & 5.28 & 0.41 \\
\hline $\mathrm{E}$ & $19 / 07 / 2000$ & -7.2 & 0.0 & -47.3 & 0.23 & 7.7 & 0.1 & 1.53 & 0.06 \\
\hline $\mathrm{F}$ & $26 / 07 / 2000$ & -7.1 & 0.0 & -45.7 & 0.75 & 8.9 & 0.1 & -1.72 & 0.32 \\
\hline $\mathrm{G}$ & $02 / 08 / 2000$ & -6.7 & 0.0 & -47.8 & 2.22 & & & -2.74 & 0.44 \\
\hline $\mathrm{H}$ & $30 / 08 / 2000$ & -6.7 & 0.1 & -49.9 & 0.23 & & & -3.26 & 0.14 \\
\hline $\mathrm{DC}$ & $12 / 07 / 2000$ & -6.6 & 0.1 & -46.6 & 0.74 & 0.9 & 0.1 & -4.05 & 0.01 \\
\hline $\mathrm{BC}$ & $12 / 07 / 2000$ & -6.6 & 0.1 & -46.7 & 0.77 & & & -5.85 & 0.07 \\
\hline
\end{tabular}

* Sampled prior to start of pumping test

Table 3a.

\begin{tabular}{|c|c|c|c|c|c|c|c|c|c|}
\hline Sample \# & Date & $\begin{array}{c}{ }^{3} \mathrm{H} \\
\text { activity } \\
\text { (TU) }\end{array}$ & $\begin{array}{c}+/- \\
(1 \mathrm{SD})\end{array}$ & $\begin{array}{c}\delta^{13} \mathrm{C} \\
\text { specific } \\
\text { (VPDB) }\end{array}$ & $\begin{array}{c}+/- \\
(1 \mathrm{SD})\end{array}$ & $\begin{array}{c}\delta^{13} \mathrm{C} \\
\text { bulk } \\
(\text { VPDB })\end{array}$ & $\begin{array}{c}+/- \\
(1 \mathrm{SD})\end{array}$ & $\begin{array}{c}{ }^{14} \mathrm{C} \\
(\mathrm{pmc})\end{array}$ & $\begin{array}{c}+/- \\
(1 \mathrm{SD})\end{array}$ \\
\hline $\mathrm{A}^{*}$ & $09 / 07 / 2000$ & 11.6 & 0.58 & -7.6 & 0.1 & -7.96 & 0.01 & 24.09 & 0.3 \\
\hline $\mathrm{B}$ & $11 / 07 / 2000$ & & & -7.3 & 0.2 & -7.92 & 0.00 & & \\
\hline $\mathrm{C}$ & $12 / 07 / 2000$ & 10.3 & 0.55 & -7.6 & 0.6 & -7.76 & 0.00 & 26.16 & 0.25 \\
\hline $\mathrm{D}$ & $13 / 07 / 2000$ & & & -7.4 & 0.5 & -6.58 & 0.00 & & \\
\hline $\mathrm{E}$ & $19 / 07 / 2000$ & 11.1 & 0.61 & -8.9 & 0.4 & -7.51 & 0.00 & 24.57 & 0.24 \\
\hline $\mathrm{F}$ & $26 / 07 / 2000$ & 12.6 & 0.61 & & & -6.82 & 0.00 & 24.68 & 0.23 \\
\hline $\mathrm{G}$ & $02 / 08 / 2000$ & 10.2 & 0.5 & -7.4 & 0.5 & -8.80 & 0.00 & 24.52 & 0.24 \\
\hline $\mathrm{H}$ & $30 / 08 / 2000$ & 10 & 0.55 & -5.4 & 0.2 & -7.15 & 0.00 & 25.34 & 0.2 \\
\hline $\mathrm{DC}$ & $12 / 07 / 2000$ & & & & & & & & \\
\hline $\mathrm{BC}$ & $12 / 07 / 2000$ & 12.2 & 0.57 & -13.3 & 0.5 & -4.28 & 0.08 & 24.64 & 0.26 \\
\hline
\end{tabular}

* Sampled prior to start of pumping test

Table 3b. 


\section{List of Figures}

Fig. 1 (a) Schematic diagram showing a plan view of the extent of the Deerplay Colliery workings and the locations of the original Black Clough and the (treated) River Irwell discharges (after Barnes 2000; Nuttall et al. 2002a). The filled star symbol shows the location of the Abstraction ( $A b s$ ) borehole drilled in the western mineworkings; (b) Log section of the abstraction ( $A b s)$ borehole, which was driven to intercept a roadway within the Deerplay workings (after Nuttall et al. 2002a); (c) NW-SE profile section of the Deerplay and surrounding mine workings (see text and Supporting Information (SI) - History of the Deerplay workings). Open connections and their levels between different mineworkings are shown by bold arrows; closed connections are also marked. Also shown schematically by the dashed lines are successive positions of the water table within the workings, at weekly intervals during the step-test pumping of $A b s$, illustrating the stages in the evolution of water levels at which, for instance, specific overflows were underdrained and left dry, and impounded minimum water levels were established in parts of the workings remote from the pumping well (from IMC Consulting Engineers 2000).

Fig. 2 Monitored analyses for pumped Deerplay waters over the course of step-testing for (a) Specific Electrical Conductivity (SEC, $\left.\mu \mathrm{S} / \mathrm{Cm} @ 25^{\circ} \mathrm{C}\right)$; (b) dissolved $(\mathrm{X}=) \mathrm{Cl}^{-}$and $(\mathrm{X}=) \mathrm{SO}_{4}{ }^{2-}$ concentrations (mg/l); (c) iron species [Fe(II), Fe(III)]. The dates of sampling of the Deerplay (Abs, pumped) waters for isotopic characterisation are also shown (samples A-H), as are the periods of step-testing (Table 1). (d) Monitored oxygen isotope fractionation $\left[\Delta^{18} \mathrm{O}_{\mathrm{SO} 4-\mathrm{H} 2 \mathrm{O}}=\delta^{18} \mathrm{O}\left(\mathrm{SO}_{4}\right)-\delta^{18} \mathrm{O}\left(\mathrm{H}_{2} \mathrm{O}\right)\right]$ over the course of steptesting for the isotopic samples (A-F; up to end of Step 2 of pumping), and for comparison the surface discharge through mine tailings spoil at Deerplay (DC). Error Bars are 2xStandard Error.

Fig. 3 Cross-plot of water isotopes $\left(\delta^{2} \mathrm{H}, \delta^{18} \mathrm{O} \%\right.$ referenced to the VSMOW standard) for the pumped Deerplay waters and also the Black Clough (adit) discharge (BC) and also the discharge through mine tailings spoil at Deerplay (DC). The solid trend line shows the Global Meteoric Water Line (GMWL) as defined by Craig (1961): $\delta^{2} \mathrm{H}(\%)=8 . \delta^{18} \mathrm{O}(\%)+10$; the slope of 8 for the GMWL (Dansgaard, 1964) generally reflecting meteoric waters samples unaffected by evaporation. Error Bars are 2xStandard Error $=2 \mathrm{xSD} / \sqrt{ } \mathrm{N}$.

Fig. 4 Cross-plot of dissolved $\mathrm{SO}_{4}{ }^{2-}$ versus $\mathrm{Cl}^{-}$for the isotopic samples (Abs borehole Samples A-H) and the surface discharges from the Black Clough ( $B C$ adit) and through mine tailings spoil at Deerplay $(D C$ discharge).

Fig. 5 Genetic cross-plot of $\delta^{18} \mathrm{O}\left(\mathrm{SO}_{4}\right)$ versus $\delta^{34} \mathrm{~S}\left(\mathrm{SO}_{4}\right)$ for the dissolved sulfate from the pumped Deeplay waters (samples A-F; up to end of Step 2 of pumping) and the samples (DC) the discharge through mine tailings spoil at Deerplay for comparison. Error Bars are 2xStandard Error

Fig. 6 Cross-plots of $\delta^{34} \mathrm{~S}\left(\mathrm{SO}_{4}\right)$ against (a) $1 / \mathrm{SO}_{4}$ and (b) the fraction $(m)$ being derived from secondary oxidation by $\mathrm{H}_{2} \mathrm{O}$ (see SI-Sulfur isotope systematics) for the pumped Deerplay waters and also the Black Clough (adit) discharge (BC) and the discharge through mine tailings spoil at Deerplay (DC). Similarly for $\delta^{18} \mathrm{O}\left(\mathrm{SO}_{4}\right)$ against (c) $1 / \mathrm{SO}_{4}$ and $(\mathrm{d})$ the fraction $(m)$ being derived from secondary oxidation by $\mathrm{H}_{2} \mathrm{O}$. For (b) and (d) the stippled line shows the trend-line for samples B-D extrapolated back to the y-axis $(m=0)$. Error Bars are 2xStandard Error 




(c) Deerplay Minewater Levels: Drawdown Phase Updated to 18/09/00

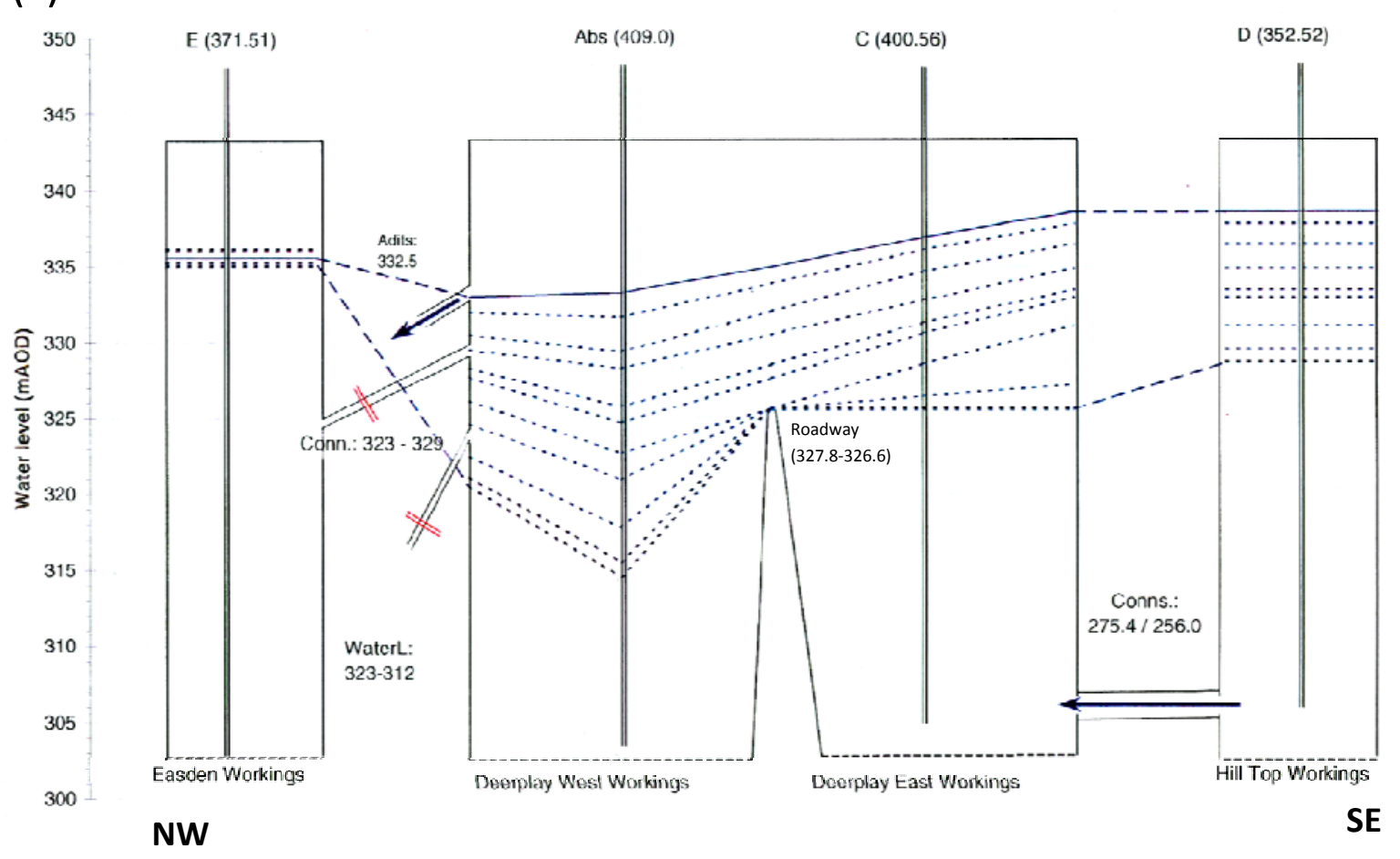




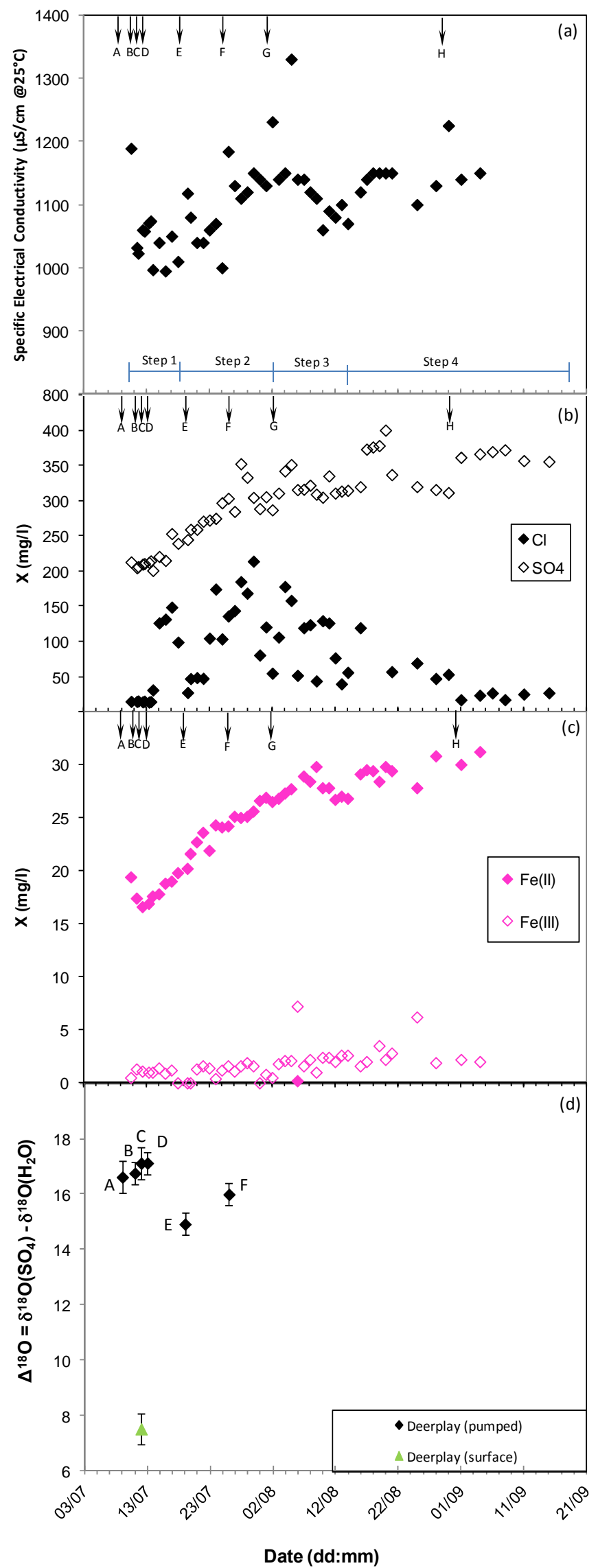

Figure 2. 


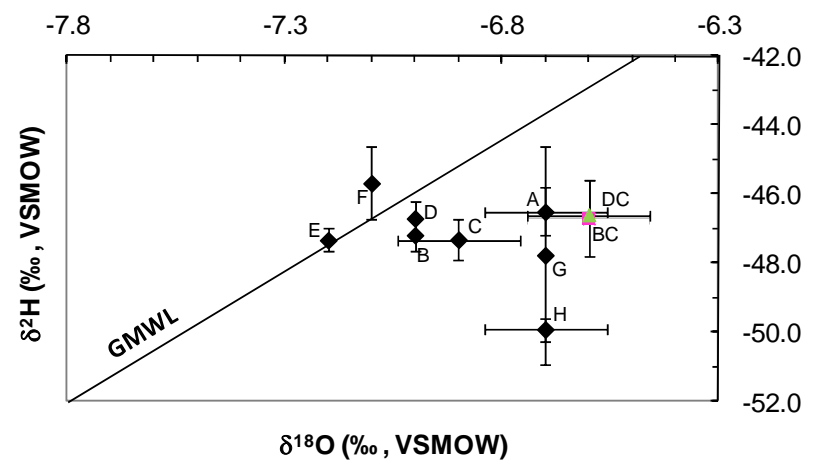

Figure 3. 




Figure 4. 


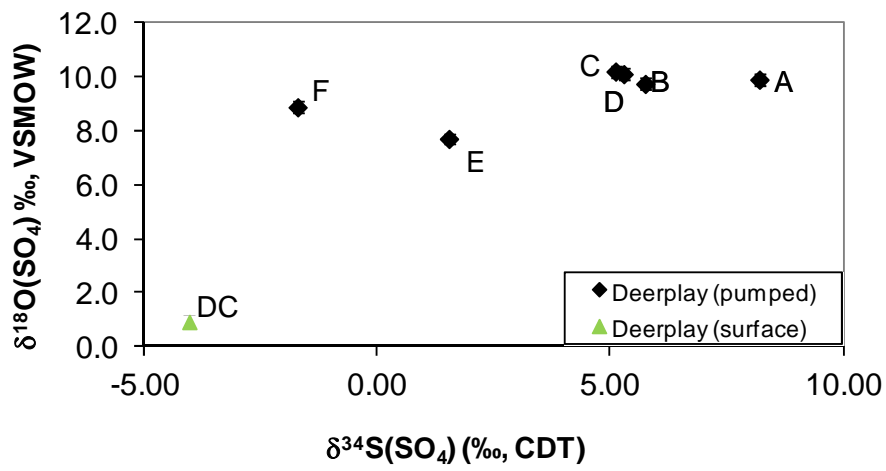

Figure 5. 


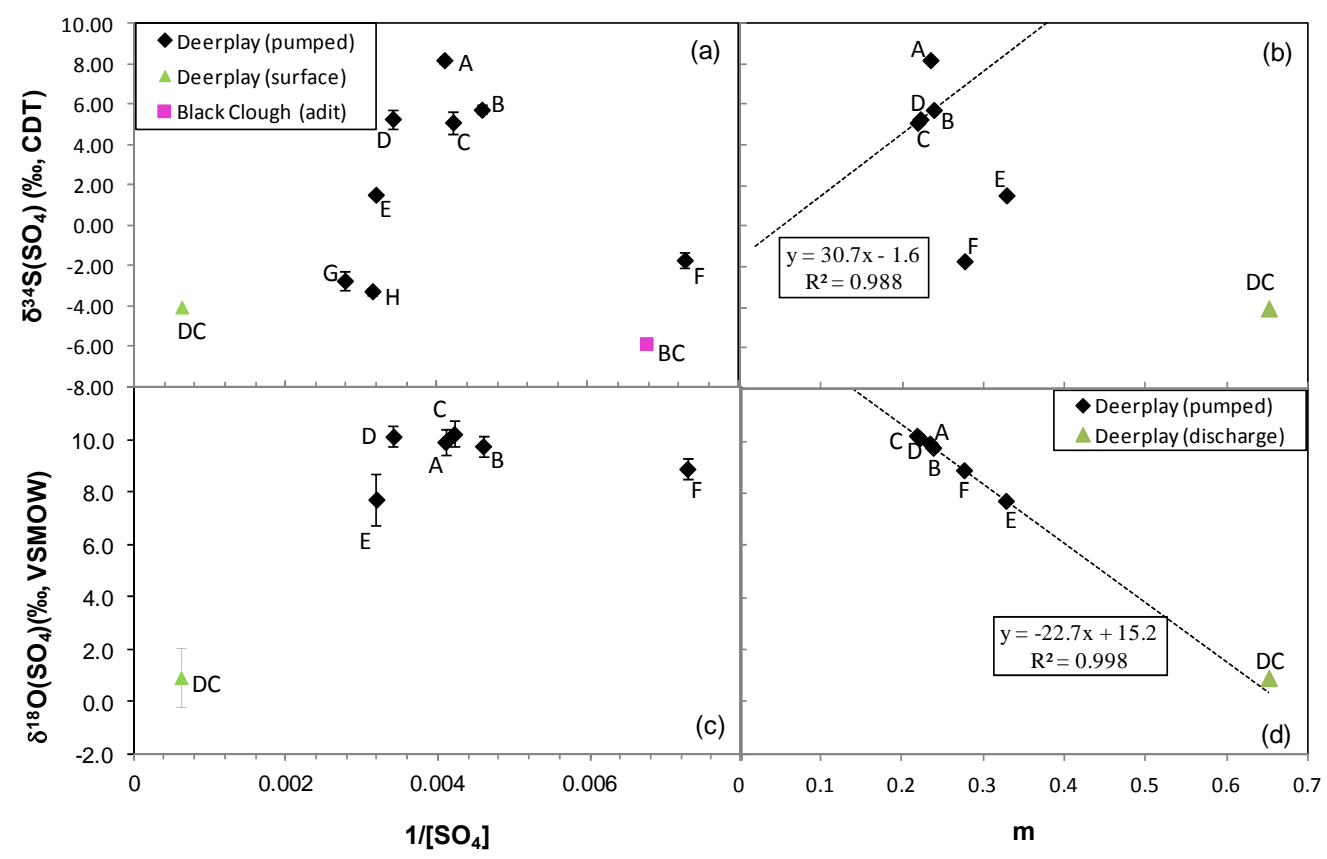

Figure 6. 